\title{
William Harvey's Soliloquy to the College of Physicians: Reprising Terence's Plot
}

\author{
MARJORIE O'ROURKE BOYLE*
}

William Harvey published his new cardiology not only from "ocular demonstrations" and "reasoned arguments" $"$ but also with literary genius. His natural philosophy has been appreciated; ${ }^{2}$ his cultured wit, ignored. A genius was classically every person's natal god, the guardian spirit of innate talent who fostered invention. Roman comedy, which Harvey exploits, developed its root, gignere, "to engender", into semen, virility, creative energy. ${ }^{3}$ In Renaissance culture genius begot emulation, in Erasmus's excellent theory an imitation beyond mimicry that surpassed the ancient masters by cultivating a native gift. ${ }^{4}$ So Harvey ingeniously introduces his book to his fellows in the College of Physicians, London, by reprising a familiar role. "If something should be useful and advantageous to the literary republic from my labour in this part", he pleads, "perhaps it might be granted that I had acted rightly, and others might see that I have not lived utterly unskilled, and as the old man says in the Comedy: 'Nobody has ever had such a well worked-out plan of life that circumstances, age, and experience don't introduce some new factor, teach some new lesson, so that you no longer know what you thought you knew and you reject in practice what you had reckoned to be of prime importance"". 5 His appropriation of this soliloquy from Terence's Adelphi graces his first chapter significantly. For, as Harvey understood from his humanist studies, rhetoric is not sophistical but epistemic: ${ }^{6}$ truthful by persuasive argument, rather than coercive logic. And the truth of his discovery about the blood's circulation is what Harvey urges on his fellows "for the love of the truth". As he argues, "Certainly true philosophers, who blaze with the love of truth and wisdom, never consider

\section{(C) Marjorie O’Rourke Boyle 2008}

* Marjorie O'Rourke Boyle, MA, PhD, is an independent scholar, residing at 95 Normandy Boulevard, Toronto, Ontario, Canada M4L 3K4.

\footnotetext{
${ }^{1}$ William Harvey, Exercitatio anatomica de motu cordis et sanguinis in animalibus, facsimile rpt. of Frankfurt, William Fitzer, 1628; Birmingham, AL, Classics of Medicine Library, 1978, pp. 5, 58. Translations of Harvey are mine.

${ }^{2}$ See Roger French, William Harvey's natural philosophy, Cambridge University Press, 1994.

${ }^{3}$ Marjorie O'Rourke Boyle, Petrarch's genius: pentimento and prophecy, Berkeley and Los Angeles, University of California Press, 1991, pp. 20-2.

${ }^{4}$ Idem, Erasmus on language and method in theology, University of Toronto Press, 1977, pp. 39-57. See also Thomas M Greene, The light in Troy: imitation and discovery in Renaissance poetry, New Haven, CT, Yale University Press, 1982;
}

George W Pigman III, 'Versions of imitation in the Renaissance', Renaiss. Q., 1980, 33: 1-32.

5 "Denique vt si quid reipub. literariae ex opera mea vtile, \& commodum hac in parte accederet, forsan recte fecisse me constaret, nec alii omnino inertem me vixisse viderent, \& quod senex ait in Comoedia (Nunquam quisquam ita bene subducta ratione ad vitam fuit, / Quin res, aetas, vsus aliquid apportet noui,/ Aliquid admoneat, vt illa qua te scire credas, nescias. / Et quae tibi putaris prima in experiundo repudies.)" Harvey, op. cit., note 1 above, p. 21.

${ }^{6}$ For an introduction to humanist rhetoric, see Boyle, op. cit., notes 3 and 4 above. For an introduction to Aristotle's epistemic rhetoric, see Chaïm Perelman and Lucie Olbrechts-Tyteca, Traité de l'argumentation: la nouvelle rhétorique, 2 vols in 1, Paris, Presses universitaires de France, 1958. For general orientation, see Walter Jost and Wendy Olmsted (eds), A companion to rhetoric and rhetorical criticism, Oxford, Blackwell, 2004. 


\section{Marjorie O'Rourke Boyle}

themselves so wise, full of wisdom, or abound in their own understanding so that they do not yield place to the truth, from whomever and wherever it may come".

Harvey explains how, in private conversation and public lecture about the movement of the heart and the blood, in "the academic custom ... I did not fear to propose my opinion in this matter". But dissenters in the College falsely accused him of "the vice that I departed from the teachings and the belief of all anatomists". Other fellows, perceiving "something new" that might prove useful, sought from him a fuller explanation. So, pressured by the slander of his detractors to defend his case and persuaded by the desire of his supporters to share in his labours, he published Exercitatio anatomica de motu cordis et sanguinis in animalibus. He did this freely, he justified, because his master in anatomy, Girolamo Fabrici d'Aquapendente, among his accurate and learned treatises on the bodily organs omitted only the heart. ${ }^{8}$

Balancing the courtesy his profession expects and the integrity that truth requires, Harvey pays lip service to tradition while subverting it. This is not duplicity because by rhetorical convention an introduction functioned to secure the good will of its readers. Not frontal attack but oblique manoeuvre was politic. Both an affectation of modesty and a declaration of novelty were standard practice. ${ }^{9}$ Harvey modestly demurs that he will not detract his forefathers, although he will proceed to do just that. "I do not endeavour, nor do I consider it favourable either to defraud anyone of the ancients of due honour or to provoke anyone of their successors. Nor do I think to fight with or contest the integrity of those who excelled in anatomies and who taught me". ${ }^{10}$ His judgment, however, is that the old school does not deserve honour, so that he does not cheat it by disagreement. This school includes Fabrici, his professor of anatomy at the University of Padua, whom he honours as "distinguished ... a highly skilled anatomist and venerable elder", ${ }^{11}$ but then criticizes.

Fabrici had understood that Aristotle's "nature books" surpassed comparative anatomy with philosophical inquiry about the quiddity and causes of things. He determined not merely to learn Aristotle's animal lore bookishly or even by replicating his dissections. He determined to extend it by his own anatomical research. Not only did Fabrici supply omissions or correct errors, but also he reinvestigated animal nature at first hand and by eyewitness. In this ambitious and successful programme he published multiple monographs, ${ }^{12}$ excepting on the heart. But Harvey's dedication to cardiac research more than

\footnotetext{
7 “ob amorem veritatis ...". "Philosophi enim veri, qui amore veritatis \& sapientiae flagrant, nunquam se tam $\sigma o \phi o \zeta$, sapientia plenos reperiunt, aut suo sensu abundant, quin veritati, à quocunque \& quandocunque venerit, locum dent". Harvey, op. cit., note 1 above, p. 7. Note the parallel between philosophical burning with wisdom and physiological burning heart as his subject.

8 "Ex quo non solum priuatim amicis, sed etiam publice in praelectionibus meis anatomicis, Academico more, proponere meam in hac re sententiam non verebar. Quae cum aliis (vti sit) placebat, aliis minus: hi conuellere, calumniari, \& vitio vertere, quod à praeceptis, \& fide omnium Anatomicorum discesserim: Illi rem nouam cum inquisitu dignam tum maxime vtilem fore
}

confirmantes, plenius sibi explicatam poscere". Ibid., pp. 10, 17, 55, 21.

${ }^{9}$ See Ernst R Curtius, European literature and the Latin Middle Ages, transl. Willard R Trask, London, Routledge and Kegan Paul, 1953, pp. 83-6.

10 "Tum quod neque à veteribus quemquam debito honore defraudare, neque è posterioribus quemquam irritari aequum censeam, aut moliar. Neque cum iis qui in Anatomicis antecelluerunt, \& me docuerunt, manus conferere, aut dimicare honestum putem". Harvey, op. cit., note 1 above, p. 8.

11 "Clarissimus Hieronym. Fabr. ab Aq ... : peritissimus Anatomicus \& venerabilis senex ...". Ibid., p. 55.

${ }^{12}$ Andrew Cunningham, 'Fabricius and the "Aristotle Project" in anatomical teaching and research at Padua', in Andrew Wear, Robert K French, 
supplied the sole organ Fabrici had neglected or avoided. The heart was the principal organ. Aristotle's natural philosophy was cardiocentric, in direct competition with Galen's medicine, which honoured the brain as the seat of the soul. Harvey ventured beyond imitation to emulation: he asserted his genius above and against others. For, if the discovery of the circulation of the blood was a methodical application of natural philosophy by rational and empirical labour, why had Aristotle himself not discovered it? Because he failed to anatomize humans? Or why had Fabrici, who did anatomize humans, not discover it? Because he failed to anatomize hearts? As an imitator of Fabrici, Harvey would have simply copied him and never discovered the circulation, any more than a modern student in a laboratory who routinely executes his professor's instructions qualifies to be named as an inventor on a patent. Indeed, Harvey did faithfully imitate Fabrici's anatomies of the crucial part, the venous membranes-until he discovered that his professor had erred at all steps of his Aristotelian project. He had misobserved and misdescribed their structure and action; and he had misreasoned their function by appropriating the wrong models, both botanical and mechanical. ${ }^{13}$

Harvey did adhere to Aristotle, even decisively but mistakenly so on the caloric cause of animation. ${ }^{14}$ But Harvey was no ape of Aristotle; nor, although a persistent hard worker, was Harvey a drudge - a septum personified. His De motu cordis et sanguinis does not read like any text of Aristotle's, however studiously Harvey may have pursued his principles, however respectfully he may have appealed to his authority for validation of his own reasonings. Nor does Harvey's text copy the scholastic monographs that initiated western thinkers to Aristotle's cardiology, Albert of Shareshill's De motu cordis ${ }^{15}$ or Thomas Aquinas's De motu cordis. ${ }^{16}$ Nor does Harvey's argumentation on the venous membranes, the most proximate part of Fabrici's many researches, resemble Fabrici's De venarum ostiolis. From its proem alone Harvey's book manifests a superbly original mind, relentlessly questioning traditional opinions: "if . . if . . if . . . what then? if . . if . . . how ... and how ... and how? and if . . why not? and if . . . why not? if . . how? and how ... if? how? if . . if . . if . . if . . if . . if . . . if . . how? why . . why . . why ... how . . why? if ... how? and how? and how? if ... if ... why? and how? why? if . . how? and why? and why? if ... why? if ... how?" There was nothing like this display of anaphora in the western canon. Cicero, whose exemplary anaphora Harvey learned as a schoolboy, stopped with six "nothing"s against the Cataline conspiracy. ${ }^{17}$ Augustine, meditating by the rhythm of his heartbeat to the eternal Word, paused between systole and diastole for only six "silence"s. ${ }^{18}$

and Iain M Lonie (eds), The medical Renaissance of the sixteenth century, Cambridge University Press, 1985, pp. 195-222. Cf. Idem, 'Aristotle's animal books: ethology, biology, anatomy, or philosophy?' Philosophical Topics, 1999, 27: 17-41.

${ }^{13}$ Harvey, op. cit., note 1 above, pp. 54-8.

Marjorie O'Rourke Boyle, 'Harvey in the sluice: from hydraulic engineering to human physiology', Hist. Technol., 2008, 24: 1-22.

${ }^{14}$ Harvey, op. cit., note 1 above, pp. 42, 58-60, $61,65$.

${ }^{15}$ Alfred of Shareshill, Des Alfred von Sareshel Alfredus Anglicus Schrift 'De motu cordis', ed.
Clemens Baeumker, 2 vols, Beiträge zur Geschichte der Philosophie des Mittelalters, vol. 23, Münster, Aschendorff, 1923, 1-2, pp. 1-114.

${ }^{16}$ Thomas Aquinas, De motu cordis, in Opera omnia iussu Leonis XIII P.M. edita, Rome, San Tommaso, 1976, vol. 43, pp. 91-130.

${ }^{17}$ Harvey, op. cit., note 1 above, pp. 10-19; Cicero, In Catalinam 1.1.1. See also Quintilian, Institutio oratoria 9.3 .30 .

${ }^{18}$ Augustine, Confessiones 9.10.25. Marjorie O'Rourke Boyle, 'Augustine's heartbeat: from time to eternity', Viator: medieval and Renaissance studies, 2007, 38: 19-43. 


\section{Marjorie O'Rourke Boyle}

"I cannot but wonder," understates Harvey of his rush of questions. His "if", "then", "why", and "how" repeat the premises and conclusions and the efficient and final causes of Aristotelian causal reasoning. His book is not a traditionalist confession, however. History may pose different questions about Harvey toward the medical traditions: what did he achieve? what did he think he achieved? The answers to these questions may also differ. An understanding of his self-appraisal requires more than a reiteration of his plain statements. It requires an analysis of his rhetorical arguments, which reveal that he comprehended and valued the importance of his discovery. As he concluded his preliminary cross-examination: "Therefore, from these and very many reasons of this kind, it is plain, since those things that were said before by previous men about the motion and use of the heart and the arteries upon diligent consideration seem either inconsistent, or obscure, or impossible, it will be absolutely useful therefore to inspect a little more penetratingly and to behold the matter of the arteries and the motion of the heart not only in humans but also in other universal animals having a heart. And why not also by frequent dissection of the living and by many autopsies discern and investigate the truth". ${ }^{19}$

Despite his courtesies to his fellows and forefathers, Harvey's plan is aggressive. Writing on the crucial venous membranes, he ridicules those who deny his discovery of the transit of the blood through the lungs as "the type of men who, where they wish, easily grant something to be, where they don't wish, by no means allow it". Although he claims, "I speak with the Poet", ${ }^{20}$ the notion that believing makes it so was prosaic, attributed to Julius Caesar's Bellum gallicum. Its context narrates a military strategy: how the Romans deceived the Gauls into marching into easy victory against their camp — only to be slaughtered by superior forces, even as they turned and fled. ${ }^{21}$ The translation of the best historians was young Will Harvey's task in the fifth form at the King's School, Canterbury. ${ }^{22}$ That particular book commended itself to British readers because it narrated Julius Caesar's presence in Britain, with his covert fording of the Thames to rout the enemy. ${ }^{23}$ Harvey's bellicose reference suits his surname, which derived from Germanic words for "army" and "battle". ${ }^{24}$ He forthrightly declares his campaign against the tradition with a classical citation, "The die is cast". His findings on the blood supply are so novel, he writes, that he fears not only harm from the envious but also hatred from everyone; for, adherence to custom and doctrine, as dictated by the veneration of antiquity, is second nature. "However", he determines, "now 'the die is cast', my hope is in the love of truth and in the integrity of learned minds". ${ }^{25}$ Harvey's decision imitated

\footnotetext{
19 "Itaque ex his, \& huiusmodi plurimis patet, cum ea quae dicta antehac à prioribus de motu, \& usu cordis, \& arteriarum, aut inconuenientia, aut obscura, aut impossiblia, diligentius considerati appareant: utile proinde admodum erit, paulo penitius rem introspicere, arteriarum, \& cordis motus non solum in homine sed \& aliis universis animalibus cor habentibus contemplari. Quin etiam uiuorum dissectione frequenti, multaque autopsia ueritatem discernere, \& iuestigare". Harvey, op. cit., note 1 above, p. 19.

20 “"Quod genus hominum (cum Poeta loquor) vbi volunt concedant facile posse: vbi nolunt nullo modo: hic vbi opus est verentur, vbi nihilo opus, ibi non verentur affirmare". Ibid., p. 37.
}

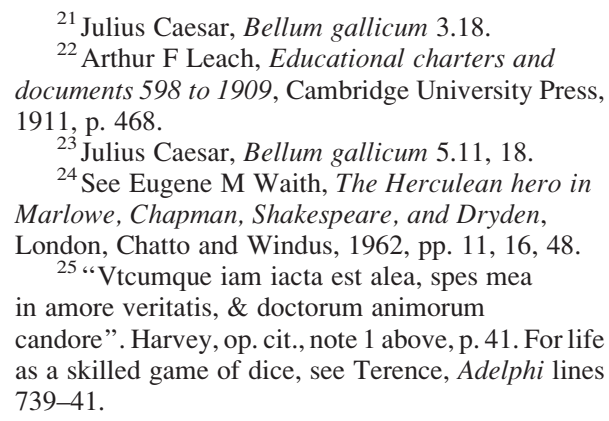

${ }^{22}$ Arthur F Leach, Educational charters and documents 598 to 1909, Cambridge University Press, 1911, p. 468.

${ }^{23}$ Julius Caesar, Bellum gallicum 5.11, 18.

${ }^{24}$ See Eugene M Waith, The Herculean hero in Marlowe, Chapman, Shakespeare, and Dryden, London, Chatto and Windus, 1962, pp. 11, 16, 48.

25 "Vtcumque iam iacta est alea, spes mea in amore veritatis, \& doctorum animorum candore". Harvey, op. cit., note 1 above, p. 41. For life as a skilled game of dice, see Terence, Adelphi lines 739-41. 


\section{William Harvey's Soliloquy to the College of Physicians}

Caesar's at the boundary of his assigned province, Cisalpine Gaul, to cross the Rubicon river to invade Italy. Plutarch had narrated the "fearful step", how Caesar's resolution wavered as he deliberated the evil for humanity or fame for himself that would follow upon the river's passage. "But finally, with a sort of passion, as if abandoning calculation and casting himself upon the future, and uttering the phrase with which men usually preclude their plunge into desperate and daring fortunes, 'Let the die be cast', he hastened to cross the river". ${ }^{26}$ Harvey is also declaring civil war-within the College.

As an emulator beyond an imitator, Harvey neatly criticizes classical medicine by quoting classical literature. Citing your opponent to your own advantage was a proved strategy in debate. ${ }^{27}$ As Shakespeare said, even "the devil can quote Scripture for his purpose", ${ }^{28}$ so costumed since the mystery plays in monk's habit or scholar's cap with those newfangled aids, eyeglasses. ${ }^{29}$ Harvey and his colleagues read the classics as schoolboys: the comedies of Terence, the poetry of Vergil and Horace, the rhetoric of Cicero and Quintilian, the histories of Julius Caesar. The royal statutes for the King's School, Canterbury, where Harvey studied, required for admission elementary Latin grammar in reading and writing. Harvey progressed to speak Latin conversationally and oratorically. He practised in drama, tales and epistles, poetry and history. He memorized rhetorical figures and poetic models, composed verses and polished topics, translated more poetry and history, and competed in short declamations. ${ }^{30}$ And long before anatomy lessons he learned powers of observation. As Erasmus's De duplici copia verborum et rerum advised him in the sixth form, "We must keep our eyes open to observe every figure of speech that they use, store it in our memory once observed, imitate it once remembered, and by constant employment develop an expertise by which we may call upon it instantly". ${ }^{31}$ At Canterbury Harvey learned Latin well enough, perhaps some Greek, to matriculate in arts at Gonville and Caius College, Cambridge. ${ }^{32}$ Although the loose undergraduate curriculum at that University largely comprised scholastic dialectic and philosophy, the first year was dedicated to rhetoric, with declamatory exercise continuing for three more years. The rhetoric lessons required a student's display of classical authors from his personal commonplace book of apt quotations. Among the literature Harvey read or reread at Cambridge were Terence's comedies and Seneca's tragedies; the poetry of Vergil, Ovid, and Horace; Cicero's orations, epistles, and philosophical treatises; Quintilian's Institutio oratoria; and Erasmus's Colloquia. ${ }^{33}$

\footnotetext{
${ }^{26}$ Plutarch, Vita Caesari 32; Plutarch's lives, transl. Bernadotte Perrin, 11 vols, Cambridge, MA, Harvard University Press, 1958, vol. 7, p. 523. Cf. Terence, Adelphi lines 739-41.

${ }^{27}$ See Aristotle, Rhetorica 1398a.

${ }^{28}$ William Shakespeare, The merchant of Venice I.iii.99.

${ }^{29}$ Jeffrey Burton Russell, Lucifer: the devil in the Middle Ages, Ithaca, NY, Cornell University Press, 1984, pp. 67-91, 211; Adolphe N Didron, Christian iconography: the history of Christian art in the Middle Ages, transl. E J Millington, 2 vols, New York, Frederick Ungar, 1965, vol. 2, pp. 127, 259-60; Gertrud Schiller, Iconography of Christian art,
}

transl. Janet Seligman, 2 vols, London, Lund Humphries, 1971-72, vol. 1, pp. 144-5.

${ }^{30}$ Leach, op. cit., note 22 above, pp. 456, 466-8.

${ }^{31}$ Erasmus, De duplici copia verborum et rerum, Betty I Knott (ed.), in Opera omnia, Amsterdam, North-Holland, 1971-, vol. I-6, p. 34; transl. Knott, in The collected works of Erasmus, Toronto, University of Toronto Press, 1974-, vol. 24, p. 303. The critical edition cited hereafter as Amsterdam.

${ }^{32}$ Geoffrey Keynes, The life of William Harvey, Oxford, Clarendon, 1966, pp. 6, 9, 14, 15.

${ }^{33}$ William T Costello, The scholastic curriculum of early seventeenth-century Cambridge, Cambridge, MA, Harvard University Press, 1958, 


\section{Marjorie O'Rourke Boyle}

This rhetorical expertise informs Harvey's De motu cordis et sanguinis. Although he was no humanist at defining or practising medicine, he was a humanist in composing and defending his exercise in natural philosophy. For, Aristotle reasoned in two disciplines, dialectic and rhetoric; and, while dialectic was the method of the natural philosophy Harvey inherited through medieval scholasticism, rhetoric was the method of the Renaissance humanism he fundamentally learned as a schoolboy. The self-referential parts of De motu cordis et sanguinis - its epistles dedicatory, proem, and first chapter-are rhetoric. So are arguments in its text, typically his examples and his metaphors or similes. Examples from similar cases were Aristotle's rhetorical counterpart to proof from dialectical induction. Metaphors and similes he esteemed for prose argument as not fanciful but disciplined. They had to be appropriate, corresponding reasonably, even beautifully, to what was signified. Their invention, Aristotle also claimed, was an unteachable art, ${ }^{34}$ so that Harvey's novel figures arguably reveal his own mind. Neither decorative as in poetry nor deceitful as in sophistry, in rhetoric metaphors and similes were cognitive. They were meaningful arguments compacted in a single word. Although Harvey's figures differ from the discursive reasoning by which he argues from premise to conclusion, they are not trivial because of the abbreviated reasoning by which he argues from point to point. Harvey's discrete words matter definitionally and argumentatively. Beyond the inquisitive rational mind recorded in his questions, his metaphors displayed his intuitive artful mind at associating the manifold evidences of nature toward a design.

Harvey studied rhetoric at the King's School, Canterbury, whose final statute enjoined the boys, "Whatever they do in earnest or in fun, they shall never use any conversation but Latin or Greek". 35 The playwright Terence had been normative in Roman education for instructing lads in conversational Latin; upon Erasmus's recommendation, Terence remained the solid choice in the English curriculum. ${ }^{36}$ By royal charter Harvey's grammar school introduced him to Terence in the third form. ${ }^{37}$ At Cambridge University, where he next studied, the humanities lecturer was known as the "Terence lecturer" because that author was the model for teaching classical Latin conversation that was idiomatic. ${ }^{38}$ As Erasmus persuaded schoolmasters in De ratione studii, "Among Latin writers who is more valuable as a standard of language than Terence? He is pure, concise, and closest to everyday speech and then, by the very nature of his subject-matter, is also congenial to the young". 39 Harvey at Canterbury read in Erasmus's De copia this example of expression by reason of cause, "Terence is the best model of diction; consequently

pp. 45-55, 31-4, 41, 43-4, 55-64; Victor Morgan with Christopher Brooke, A history of the

University of Cambridge, vol. II: 1546-1750,

Cambridge University Press, 2004, p. 511; Mark H

Curtis, Oxford and Cambridge in transition, 1558-

1642: an essay on changing relations between the

English universities and English society, Oxford,

Clarendon, 1959, p. 87.

${ }^{34}$ See Aristotle, Rhetorica 1356b, 1393a-1394a, 1405a-b, 1406b-1407a.

${ }^{35}$ Leach, op. cit., note 22 above, p. 468.

${ }^{36}$ See Thomas W Baldwin, Shakespeare's small Latine and lesse Greeke, 2 vols, Urbana, University of Illinois Press, 1944, vol. 1, pp. 641-2. See also Robert
S. Miola, Shakespeare and classical comedy: the influence of Plautus and Terence, Oxford, Clarendon, 1994.

${ }^{37}$ Leach, op. cit., note 22 above, p. 466.

${ }^{38}$ Morgan, op. cit., note 33 above, pp. 512-13.

${ }^{39}$ Erasmus, De ratione studii, ed. Jean-Claude Margolin, in Opera omnia, Amsterdam, vol. I-2, pp. 115, 148; transl. Brian McGregor, Collected works of Erasmus, vol. 24, p. 669. See also Erasmi epistolae, ed. P S Allen, et al., 12 vols, Oxford, Clarendon, 1906-58, vol. 9, pp. 401-3. For De ratione studii as "the fundamental philosophy of the grammar school in England", see Baldwin, op. cit., note 36 above, vol. 1, p. 94. 


\section{William Harvey's Soliloquy to the College of Physicians}

you should be always turning his pages". ${ }^{40}$ To keep the boys turning those pages, Erasmus elaborated the teaching of Terence's comedies. ${ }^{41}$ His annotated edition was standard, while Nicholas Udall's Flowers for Latin speaking translated and analysed excerpts. The production of Latin plays was popular in English schools and universities. At Canterbury they were staged on the dais in the old schoolroom in the almonry chapel. ${ }^{42}$ At Cambridge comedies in Latin modelled on Terence were the most popular entertainments. ${ }^{43}$ From Terence's characters Harvey was expected to learn moral philosophy toward virtuous behaviour. ${ }^{44}$

Erasmus further recommended Terence as the best master for boys to develop the faculty of invention. ${ }^{45}$ Harvey's achievement is in correct Renaissance English a discovery, or "uncovering of facts previously unknown". ${ }^{46}$ But, before he could discover it he had to invent it. Invention did not mean fictitious fabrication but factual finding, from the Latin invenire, "to find". As the first part of rhetoric, invention was the power that investigated hidden secrets. Its art determined the state of the question, then the appropriate arguments and genre for its proof or refutation. ${ }^{47}$ Harvey at Canterbury competed with the other boys in short declamations to practise such formal disputation. ${ }^{48}$ Now in De motu cordis et sanguinis he argues before his fellow physicians by seizing brilliantly on the common feature of all Roman comedies-error. From innocent mistakes to malicious deceptions, error motivated its complicated plots. Discovery, the revelation of new facts that allowed the characters' passage from ignorance to knowledge, was key to its dramatic movement. ${ }^{49}$ Harvey exploits the comedy that Terence's first commentator, Aelius Donatus, considered in his own preface a play of "multiple error". 50

Harvey quotes from Terence's Adelphi:

If something should be useful and advantageous to the literary republic from my labour in this part, perhaps it might be granted that I had acted rightly, and others might see that I have not lived utterly unskilled, and as the old man says in the Comedy: "Nobody has ever had such a well worked-out plan of life that circumstances, age, and experience don't introduce some new factor, teach some new lesson, so that you no longer know what you thought you knew and you reject in practice what you had reckoned to be of prime importance."

As schoolboys learning Latin, Harvey and his fellows had studied these opening lines of the soliloquy of the elder (senex) Demea. It spoke that protagonist's resolve to abandon his rigid pedagogy because "in reality nothing is better for a man than to be generous and

\footnotetext{
${ }^{40}$ Erasmus, op. cit., note 31 above, p. 121; Knott (transl.), Collected works of Erasmus, p. 416.

${ }^{41}$ Erasmus, De ratione studii, op. cit., note 39 above, pp. 136-46.

${ }^{42} \mathrm{C}$ E Woodruff and $\mathrm{H} \mathrm{J}$ Cape, Schola regia Canturiensis: a history of Canterbury School: commonly called the King's School, London, Mitchell Hughes \& Clarke, 1908, pp. 80, 89, 335-6.

${ }^{43}$ Brooke in Morgan with Brooke, op. cit., note 33 above, p. 38; Graham Chainey, A literary history of Cambridge, rev. ed., Cambridge University Press, 1995, pp. 22-6. See also G C Moore Smith, College plays performed in the University of Cambridge, Cambridge University Press, 1923.
}

\footnotetext{
${ }^{44}$ See Erasmus, De ratione studii, op. cit., note 39 above, pp. 136-9; Epistolae, op. cit., note 39 above, vol. 9 , p. 401.

${ }^{45}$ Erasmus, Epistolae, op. cit., note 39 above, p. 403.

${ }^{46}$ Oxford English dictionary, second unabridged edition, "discovery", s.v.

${ }^{47}$ Cicero, De inventione $1.7 .9,1.15 .61-63$.

${ }^{48}$ See Leach, op. cit., note 22 above, p. 468

${ }^{49}$ See George E Duckworth, The nature of Roman comedy, Princeton University Press, 1952, pp. 140-2, 146-75.

${ }^{50}$ Aelius Donatus, Commentum Terenti praef. 2.1.
} 


\section{Marjorie O'Rourke Boyle}

easygoing". ${ }^{51}$ A soliloquy was a dramatic monologue delivered solo by a character either alone on stage or in an aside from the other actors. A frequent feature, soliloquies varied in length, style, structure, and purpose as expository, characterizing, homiletic, or reflective. Beyond any soliloquies the College of Physicians read in school, were those performed for lucky Londoners, the finest ever composed, the soliloquies of Shakespeare. His genius transformed and transcended the tradition as characters spoke their souls. ${ }^{52}$ A soliloquy was thus a very familiar and indicative form for Harvey to quote in persona to his audience. And, since for both physicians and philosophers the heart either caused or effected the stuff of drama-the passions of the soul, soliloquies spoke the heart. The most famous soliloquy of all confessed in Stoic cardiocentrism Hamlet's deliberation on whether to end or not "the heart-ache and the thousand natural shocks/ That flesh is heir to". 53

Terence's stage direction for Adelphi indicated that Demea was alone for his soliloquy: there were no eavesdroppers onstage, only the playgoers in the pit. His soliloquy was stock classical characterization, although for Harvey and his fellows it may have resonated with the profounder psychology of the current London stage. Demea reviews his reputation as a terribly severe parent and announces his reversal of character. This soliloquy signals to the audience a forthcoming change of plot. By its citation Harvey admits to having been, like Demea toward his son, a hidebound disciplinarian who rigorously oversaw his own charge, the students of his anatomy lectures, according to strictest professional rules. By its citation he introduces a more relaxed attitude, to prepare his own audience for the unexpected arguments to follow on the heels of his borrowed soliloquy. Harvey declares a change of mind from strict conformity to medical tradition-indeed to the concept of tradition itself-and he invites the College of Physicians to imitate his conversion. Precisely when this change of mind first stirred Harvey divulges in diction, coepi egomet mecum, plucked straight from Terence's comedies. Inceptive verbs, such as "to begin", were a common narrative device in his plays. By emphasizing the beginning of an action, coepere made it lively and vivid. The emphatic form of the personal pronoun, egomet, was also frequent in Roman comedy; Terence used it thirty-three times. ${ }^{54}$ As Harvey pondered the supply and transit of the blood, "I, I began to think to myself [coepi egomet mecum] whether it had some movement as if in a circle ... which afterwards I found to be true". ${ }^{55} \mathrm{He}$ emphasized "I myself with myself" as distinct from all other

\footnotetext{
${ }^{51}$ Harvey, op. cit., note 1 above, p. 21; Terence, Adelphi lines 855-8, 860-1; John Barsby (transl.), Terence, 2 vols, Cambridge, MA, Harvard University Press, 2001, vol. 2, pp. 349, 351.

${ }^{52}$ For an introduction, see Lloyd A Skiffington, The history of English soliloquy: Aeschylus to Shakespeare, Lanham, MD, University Press of America, 1985; Wolfgang Clemen, Shakespeare's soliloquies, transl. Charity Scott Stokes, London, Methuen, 1987, pp. 1-12; James Hirsh, Shakespeare and the history of soliloquies, Madison, NJ, Fairleigh Dickinson University Press, 2003.

${ }^{53}$ William Shakespeare, Hamlet III i 62-63. The Stoic identification is mine, and I would add that Hamlet is full of Aristotelian-Stoic cardiocentrism mixed with Galenic humoral medicine. For the
}

passions, see Simo Knuuttila, Emotions in ancient and medieval philosophy, Oxford University Press, 2004; Richard J Sorabji, Emotion and peace of mind: from Stoic agitation to Christian temptation, Oxford University Press, 2000. For contemporary English theory, see Thomas Wright, The passions of the mind in general, 1601, ed. William Webster Newbold, New York, Garland, 1986.

${ }^{54}$ John Barsby (ed.), Terence, Eunuchus, Cambridge University Press, 1999, pp. 108, 133. For egomet, see, e.g., "egomet nunc mecum", "egomet mihi", Terence, Heauton timorumenos lines 385 , 507; “"egomet mihi”, idem, Eunuchus line 252.

55 "Coepi egomet mecum cogitare, an motionem quandam quasi in circulo haberet, quam postea veram esse reperi ... ". Harvey, op. cit., note 1 above, p. 41. 
thinkers. It was not for any conformity to traditional anatomy but for his change of behaviour that Harvey asked to be thought "useful and advantageous to the literary republic from my labour in this part". For that change of character, he asked his colleagues' judgment "that I had acted rightly ... and that I have not lived utterly unskilled". His phrases "in this part" and "acted rightly" dramatize his role as lecturer in the anatomy theatre. His fresh start, his new beginning announced in his proem recalls the prologue of Terence's Hecyra, which defended the play with triple coepis. ${ }^{56}$

Harvey's citation is from Terence's Adelphi ('The Brothers'), considered his masterpiece for its high moral and pedagogical purposes and for its unsurpassed characterization of the dual protagonists. Its theme is the father-son relationship, in the generational types of elders and youths. These are embodied by contrasting brothers, Demea and Micio, and their conflicting methods-strict and lenient-of raising sons. ${ }^{57}$ Erasmus instructed schoolmasters on how to teach these double father-son pairs as rhetorical types for opposite temperaments and behaviours. Yet he also offered them to schoolboys as an example of "variety in characters belonging to the same general type". As he explained, "What could be more dissimilar than Demea and Micio in Terence? Micio is mild even when he is trying to reprimand his son severely, Demea is cross-patched even when he is doing his best to be pleasant. Yet they are both old men, and brothers at that". ${ }^{8}$ This characterization is ideal for Harvey, who needs to address conflicting beliefs about his research within the College of Physicians, while maintaining its essential fraternity. Demea, whom Harvey quotes, characterizes the unreasonably severe father, who realizes that the pathetic reward for his parental toil is hatred and isolation. ${ }^{59}$ Severity, Erasmus taught educators, breeds "servility". It ruins the promising lads, who are the most vulnerable to breakdown under authoritarian discipline. ${ }^{60}$

Terence's comedies were appropriate for Harvey's address to his colleagues because they were based on the problems of family relations and obligations. ${ }^{61}$ Harvey confronts the College of Physicians with the medical father-son relationship, the historic alliance of the Hippocratic Oath between a physician and his master. That Oath classically sought to forge a strong bond between the master physician and his pupils by demanding what has been termed a "quasi-contractual relationship". Although since antiquity pupils frequently violated it by disagreement with, even blunt criticism of, their masters, ${ }^{62}$ adherence was the ideal. The neophyte physician swore "to hold my teacher in the art equal to my own parents; to make him partner in my livelihood; when he is in need of money to share it with him; to impart precept, oral instruction, and all other instruction to my own sons, the

${ }^{56}$ Terence, Hecyra lines 18, 33, 37.

${ }^{57}$ Duckworth, op. cit., note 49 above, pp. 143-4, 271, 300, see also, pp. 237-49, 285-7; Sander M Goldberg, Understanding Terence, Princeton University Press, 1986, pp. 73-4.

${ }^{58}$ Erasmus, De ratione studii, op. cit., note 39 above, p. 144; De copia, ed. Betty I. Knott, in Opera omnia, Amsterdam, vol. I-6, p. 208; transl., idem, in Collected works of Erasmus, vol. 24, p. 584. See also Epistolae, op. cit., note 39 above, vol. 1, pp. 75, 93, 157, 162, 209.

${ }^{59}$ Duckworth, op. cit., note 49 above, p. 245; and for comedic duality, see pp. 184-90.

\footnotetext{
${ }^{60}$ Erasmus, De recta pronuntiatione, ed. Maria Cytowska, in Opera omnia, Amsterdam, vol. I-4, p. 28; transl., Maurice Pope, Collected works of Erasmus, vol. 26, p. 385. Cf. Henry Peacham, The truth of our times, in The complete gentleman, The truth of our times, and The art of living, ed. Virgil B Heltzel, Ithaca, NY, Cornell University Press for the Folger Shakespeare Library, 1962, pp. 208-10.

${ }^{61}$ See Goldberg, op. cit., note 57 above, p. 21.

${ }^{62}$ Geoffrey Lloyd and Nathan Sivin, The way and the word: science and medicine in early China and Greece, New Haven, CT, Yale University Press, 2002, p. 112.
} 


\section{Marjorie O'Rourke Boyle}

sons of my teacher, and to indentured pupils who have taken the physician's oath, but to nobody else" ${ }^{63}$ Renaissance translations into English varied in weighting the extent of this filial obligation but all used the deferential name "father". 64 The Oath was necessitated historically by the extension of a familial school of medicine, the Asclepiads of Cos, to outsiders. It intended to protect the transmission of knowledge by non-kin through binding them in a kind of familial relationship. ${ }^{65}$ The physician's behaviour of filial respect and loyalty toward a paternalistic master had pride of place in the Oath, preceding his ethical obligations toward patients.

In the matter of the heart and blood, which engages Harvey in controversy with the College, traditional reverence had prevailed. Harvey recites the truisms of Galen as filial piety toward the Hippocratic writings. Although he honours Galen as "the father of physicians" and "a divine man", ${ }^{66}$ Harvey will prove to be the rebellious son who covets for himself the divine epithet. Yet, Harvey names only one elder, a venerabilis senex ${ }^{67}$ Fabrici, his anatomy professor at Padua. This play on Terence's play specifies Harvey's conflict with Fabrici's cardiac physiology but encompasses an authoritarian lineage regressing to Galen. Not only was adherence to Galen's medicine rigid in general, ${ }^{68}$ but in particular Thomas Linacre, physician and humanist, had cemented the foundation of the College with his translations of Galen's De usu pulsuum and other works. ${ }^{69}$ Harvey had educational and professional ties to Linacre: both were graduates of the King's School, Canterbury, and MD from the University of Padua; both served as English royal physicians; both belonged to the College of Physicians, whose first president was Linacre. Another filial entanglement was Harvey's debt to John Caius, whose eponymous Cambridge college graduated him. To train Harvey's memory of this debt, it was statutory practice on the day after the end of term for the college to assemble in chapel to commemorate its founder, then recite prayers prefaced by the verse, "The memory of the righteous shall remain for evermore" 70 Caius's collegiate statutes allowed its medical fellows, such as Harvey, a leave of absence to study abroad and they recommended the University of Padua, ${ }^{71}$ from which Harvey was graduated a doctor in medicine and arts. ${ }^{72}$

A physician and humanist, it was Caius who, as president of the College of Physicians, revised its statutes to exact a knowledge of Galen as conditional for membership. He

\footnotetext{
63 'The Oath', in Hippocrates, transl. W H S Jones, 2 vols, London, William Heinemann, 1923, vol. 1, p. 298; transl., p. 299.

${ }^{64}$ Sanford V Larkey, 'The Hippocratic Oath in Elizabethan England', Bull. Hist. Med., 1936, 4: 201-19, on pp. 203, 212, 216, 218.

${ }^{65}$ Jacques Jouanna, Hippocrates, transl. M B DeBevoise, Baltimore, Johns Hopkins University Press, 1999, pp. 43-52.

${ }^{66}$ Harvey, op. cit., note 1 above, pp. 31, 32. See also Helen King, 'The power of paternity: the father of medicine meets the prince of physicians', in David Cantor (ed.), Reinventing Hippocrates, Aldershot, Ashgate, 2002, pp. 21-36, on pp. 21-2, 27-8.

${ }^{67}$ Harvey, op. cit., note 1 above, p. 55 .

${ }^{68}$ See George N Clark, A M Cooke, and Asa Briggs, A history of the Royal College of Physicians of London, 4 vols, Oxford, Clarendon
}

for the Royal College of Physicians, 1964-2005, vol. 1, pp. 165-6.

${ }^{69}$ See Giles Barber, 'Thomas Linacre: a bibliographical survey of his works', in Francis Madison, Margaret Pelling and Charles Webster (eds), Essays on the life and work of Thomas Linacre, $c$. 1460-1524, Oxford, Clarendon, 1977, pp. 290-336, on p. 303; Richard J Durling, 'Linacre and medical humanism', in ibid., pp. 76-106, on pp. 94-5. See also Webster, 'Thomas Linacre and the foundation of the College of Physicians', in ibid., pp. 198-222.

${ }^{70}$ See Morgan, op. cit., note 33 above, p. 211.

${ }^{71}$ Curtis, op. cit., note 33 above, pp. 153-4.

${ }^{72}$ See Jerome Bylebyl, 'Medicine, philosophy, and humanism in Renaissance Italy', in John W Shirley and F David Hoeniger (eds), Science and the arts in the Renaissance, Washington, DC, Folger Shakespeare Library, 1985, pp. 27-49, on pp. 29-34, 43. 
himself set the example with his assiduous scholarship on Galen's texts. In another filial complication, Harvey's father-in-law, Lancelot Browne, also a physician and fellow of the College, had transcribed Caius's marginal notes into his own copy of Galen. A substantial source for Galen that Caius used and Browne copied was the Codex Adelphi. ${ }^{73}$ If Harvey knew that, his clever play with Terence's Adelphi was all the more poignant. Harvey's choice of Terence as a reformatory model embedded the issue of the Latin imitation of Greek sources, for his Latin comedies were based on Greek texts, his Adelphi on Menander's Adelphoe. A literary controversy presaged a medical conflict.

The comedic type of the old man (senex) whom Harvey quotes from Terence's Adelphi was a scolder. Erasmus expected teachers to explain that "even the sweetness of Demea has a touch of bitterness to it". ${ }^{74}$ Indeed, in the initial and influential commentary, by Donatus, Demea only pretends to change his mind. ${ }^{75}$ Harvey, nevertheless, quotes Demea's soliloquy straightforwardly as exemplary of his own radical change of mind and character. He pleads for his colleagues also to act the part of Demea, learned in school, so as to abandon their stubborn loyalty to Galenic medicine and be generous toward his own inventive demonstrations. In asking his colleagues to play that changing character, Harvey also identifies himself with Terence. That author was accused by jealous fellow playwrights of contaminating their common Greek sources, much as Harvey reports the envy of some of his fellows who accuse him of transgressing Galen in the restored Greek editions of Thomas Linacre, their founder, and John Caius, also a past president. As Terence summons his audience by defending his Adelphi in its prologue, "The playwright is aware that his works are being subjected to unfair criticism and that his opponents are misrepresenting the play we are about to perform. He himself will present the evidence in his own trial, and you shall judge whether what he has done merits praise or censure.... See that you give the play a fair hearing and encourage the author to continue with the task of writing". 76

Harvey personifies the medical Antiquity to which his colleagues adhere as a "schoolmistress", employing a rare word, magistra, from another of Terence's comedies, Hecyra ('The Mother-in-Law'). Since that play twice failed, it too pleads in its prologue for a fair showing. ${ }^{77}$ Laches, like Demea another old man (senex), complains that women are "all schooled to wickedness in the same school. In the name of gods and men, what a breed they are, what a gang of conspirators! All women have identical likes and dislikes about everything! You can't find a single one whose character differs in any respect from the others". He points to Sostrata as their magistra, or "headmistress". ${ }^{78}$ This female "gang of conspirators" is literally a coniuratio, or "swearing together". Harvey's magistra alludes to the Hippocratic and Collegiate oaths, by which physicians collectively swore

\footnotetext{
${ }^{73}$ Vivian Nutton, John Caius and the manuscripts of Galen, Cambridge, Cambridge Philological Society, 1987, pp. 60, 85-6, 106; idem, 'John Caius and the Linacre tradition', Med. Hist., 1979, 23: 374-91, on p. 380; idem, " "Prisci dissectionum professiores": Greek texts and Renaissance anatomists', in A C Dionisotti, Anthony Grafton and Jill Kraye (eds), The uses of Greek and Latin, historical essays, London, Warburg Institute, University of London, 1988, pp. 111-26, on p. 121.
}

\footnotetext{
${ }^{74}$ Erasmus, De ratione studii, op. cit., note 39 above, pp. 143, 144 .

${ }^{75}$ Donatus, Commentum Terenti ad line 992.

${ }^{76}$ Terence, Adelphi prol. 1-5, 24-25; Barsby (transl.), op. cit., note 51 above, vol. 2, pp. 255, 257. See also Goldberg, op. cit., note 57 above, pp. 31-60, 91-122; Duckworth, op. cit., note 49 above, pp. 61-5.

${ }^{77}$ See Goldberg, op. cit., note 57 above, pp. 56-8.

${ }^{78}$ Terence, Hecyra lines 198-204; Barsby (transl.), op. cit., note 51 above, vol. 2, pp. 164-5.
} 


\section{Marjorie O'Rourke Boyle}

fidelity to schoolmistress Antiquity. Harvey counters this effeminacy with his own oath against Galen's error on the septum, "by Hercules", the classical oath that was exclusive to males. ${ }^{79}$ As the elder Laches explains, "If I knew a more solemn way to convince you of my truthfulness than by swearing an oath, I would use it". ${ }^{80}$ Harvey wants his colleagues to adapt Laches' advice to schoolmistress Sostrata to have a change of mind, as did Demea in Adelphi. As Laches pleads, "It shows good sense to be willing to change your mind when the need arises, and to do now what you might well have to do later". ${ }^{81}$ The change of mind Harvey requires means not merely the abandonment of a medical idea but also the social realignment of the medical family. This bond is of ancient lineage, the medical quasi-kinship, a professional society with involvements and obligations, established on the Hippocratic Oath of allegiance to masters as fathers and reinforced by the Collegiate oath of fellowship.

Harvey's citation of Terence's old man (senex) introduces the classical and biblical topic, current in hagiography and eulogy, of puer-senex, the child mature beyond his years. ${ }^{82}$ With his alteration of puer to iuvenus Harvey indicates himself to promote his own precosity. Posing as a "youth" among his fellows, Harvey asks the "elders" to change their minds, as did Demea, to make a comedy, or happy ending, to their mistakes. Terence's Adelphi was read and performed in the English schools; ${ }^{83}$ his colleagues had to know the lesson. Harvey argues that learned, good, and honourable men "do not think it demeaning to revise their judgment if the truth of open demonstration persuades, or dishonourable to abandon errors, even the most venerable ones". Proverbially, to be human is to err, he continues, and "anyone can learn from anyone, an old man from a youth [a iиuene senex], an intellectual from a fool". ${ }^{84}$ But, by citing Terence's model of an altered mentality, Harvey the "youth" casts himself oxymoronically as an elder, who exceeds his fellows in knowledge. The youth as a stock character of Roman comedy was the lover. Harvey is such a lover, appealing vigorously in his epistle dedicatory to the love of truth and wisdom that his colleagues profess. ${ }^{85}$

In this youthful-elderly part he also rehearses the role of Galen, who in De methodo medendi assigned his desire for true knowledge to his youth. "I do not know how it happened, miraculously or by divine inspiration, or in a frenzy or whatever you may

\footnotetext{
${ }^{79}$ Harvey, op. cit., note 1 above, p. 18. Ashley Montagu, The anatomy of swearing, New York, Macmillan, 1967, pp. 31-2. The undocumented locus classicus is Aulus Gellius, Noctes atticae 11.6.1, which explains that females did not swear by Hercules because they did not sacrifice to him. For Gellius, see Erasmus, De ratione studii, op. cit., note 39 above, p. 120. For hercle/mehercle sworn only by men in Terence's plays, see also Duckworth, op. cit., note 49 above, p. 333.

${ }^{80}$ Terence, Hecyra line 750; Barsby (trans1.), op. cit., note 51 above, vol. 2, p. 225. For hercle, see line 783; for Asclepius and Hygieia of the Hippocratic Oath, see line 337.

${ }^{81}$ Terence, Hecyra lines 608-9; Barsby (transl.), op. cit., note 51 above, vol. 2, p. 211.

${ }^{82}$ For the topic, see Curtius, op. cit., note 9 above, pp. 98-101. See also Erasmus, Adagia, in Opera
}

omnia, ed. Johannes Clericus, 11 vols, Leiden, 1803-7, vol. 2, p. 1070.

${ }^{83}$ See Baldwin, op. cit., note 36 above, vol. 1 , pp. 152 n.18, 177-8, 294, 336-7, Micio and Demea at pp. 348,438 .

84 "Omnes item studiosi, boni, honestique, nunquam ita passionibus indignationis, inuidiae, obrui mentem sinunt, quo minus audiant aequo animo quae pro veritate proferantur, aut rem vere demonstratam intelligant. nec turpe putant mutare sententiam si veritas suadet \& aperta demonstratio: nec errores, licet antiquissimos deserere arbitrantur inhonestum". Harvey, op. cit., note 1 above, p. 8. See Morris P Tilley, A dictionary of proverbs in England in the sixteenth and seventeenth centuries, Ann Arbor, University of Michigan Press, 1950, p. 190.

${ }^{85}$ Harvey, op. cit., note 1 above, pp. $7-8$. 


\section{William Harvey's Soliloquy to the College of Physicians}

call it, but from my very youth I despised the opinion of the multitude and longed for truth and knowledge, believing that there was for man no possession more noble than divine". 86 Yet, by Harvey's era Galen's youthful aspiration had solidified into the very "opinion of the multitude" that Harvey contests. Harvey would re-enact Galen's role by following Galen's script that whoever would surpass the crowd in knowledge must exceed it in talent and education. As Galen wrote of the aspiring physician, "And when he approaches adolescence, he must fall madly in love with truth, like one divinely inspired". Galen's method, however, was youthful exertion to "learn thoroughly all that has been said by the most illustrious of the ancients". Harvey heeds, rather, Galen's qualification that the young lover must test and judge this ancient knowledge "with obvious fact" to determine what is agreeable or disagreeable. ${ }^{87}$ Harvey early learned a prudent mentality toward traditional texts from Quintilian's rhetoric, which governed the English grammar school curriculum. ${ }^{88}$ Its Institutio oratoria defined art as an imitation of prescribed standards but cautioned that imitation was disadvantageous without careful discrimination. ${ }^{89}$

An exemplar of the puer-senex Harvey's colleagues knew well was Vergil's “fair Iülus, with a man's mind and a spirit beyond his years". ${ }^{90}$ Harvey's medical precedent was a character in Historia Apollonii regis tyri, "the student of the doctor, a young man in appearance, but an old man in wisdom". In that wildly popular romance a young physician arrives on the scene just as his master is about to torch the corpse of a beautiful girl who has washed up on shore in a coffin. The youth obeys his master's instructions to anoint the cadaver but discovers by suspicious examination of her praecordia the stillness and numbness of her breast. In amazement he realizes that she reposes in a false death. The young physician takes her pulse, checks her nostrils for breath, and tests her lips with his. Sensing a struggle between life and death, he orders fires lit at the four corners of the coffin, until her coagulated blood liquefies. Excitedly the youth announces, "Master, the girl whom you believe dead is alive" ". He proceeds to prove his diagnosis by applying warm oil to her breast until her veins clear and her spirit penetrates her marrow. Then, "When the young man saw that through his skill he had noticed what his teacher had missed, he was overjoyed. He went to his teacher and said: 'Come, master, look at your pupil's demonstration'. The teacher came into the bedroom, and when he saw that the girl whom he had believed to be dead was now alive, he said to his pupil: 'I commend your skill, I praise your knowledge, I admire your attentiveness"," 91

With his plea to his colleagues that an elder can learn from a youth, Harvey solicits a replay of this thrilling drama of life snatched from death. He wants his own initiative of

\footnotetext{
${ }^{86}$ Galen, De methodo medendi, in Opera, ed. Karl Gottlob Kühn, 22 vols in 20, Leipzig, 1821-33, vol. 10, p. 457, cited by Owsei Temkin, Galenism: the rise and decline of a medical philosophy, Ithaca, NY, Cornell University Press, 1973, p. 10.

${ }^{87}$ Galen, De naturalibus facultatibus, in op. cit., note 86 above, vol. 2, pp. 179-80, cited by Temkin, op. cit., note 86 above, p. 32. For Linacre's translations, see Barber, op. cit., note 69 above, pp. 297-99, 303; Durling, op. cit., note 69 above, pp. 87-9, 95-7.

${ }^{88}$ For Quintilian, see Baldwin, op. cit., note 36 above, vol. 2, pp. 197-238.

${ }^{89}$ Quintilian, Institutio oratoria 10.2- 4-10.2.19.
}

\footnotetext{
${ }^{90}$ See Vergil, Aeneid 9.641-42. G Karl Galinksy, The Herakles theme: the adaptations of the hero in literature from Homer to the twentieth century, Oxford, Basil Blackwell, 1972, p. 35. Harvey's use of the puer-senex topic also imitates Andreas Vesalius, who in the preface to De fabrica complained that his youth has provoked the envy of his elders. Andreas Vesalius, De humani corporis fabrica libri septem, Basel, I Oporini, 1543, fol. 4r.

${ }^{91}$ Historia Apollonii regis tyri, in Apollonius of Tyre: medieval and Renaissance themes and variations, ed. Elizabeth Archibald, Cambridge, D S Brewer, 1991, pp. 140-1.
} 


\section{Marjorie O'Rourke Boyle}

observation and demonstration for the resolution of a grave physiological error to be recognized and praised, just as that master physician had commended his young pupil. Like Terence's Adelphi, the themes of Historia Apollonii are filial piety-in its dual father-daughter and master-pupil relationships-and the role of education. This late antique novel not only survived in more than a hundred Latin manuscripts but was also translated into twelve vernaculars, beginning with Old English. ${ }^{92}$ The Elizabethan translation by Laurence Twine, The patterne of painefull adventures, was reprinted in London in 1607, during Harvey's residence there. It presented Harvey's puer-senex in the "scholler in Physicke, whose name was Machaon, very towardly in his profession, of yeres but yong, but antient in wit and experience". 93 In 1608 a version of the original romance, George Wilkins's The painefull aduentures of Pericles Prince of Tyre, reinstated Cerimon as the physician who usurps the diagnostic and therapeutic roles of his young student. ${ }^{94}$ Wilkins collaborated with William Shakespeare on a dramatization of the novel, Pericles. It was first staged in 1607-8 in London's public theatres, later in 1619 in the great chamber at the court of James I, where Harvey was physician extraordinary. ${ }^{95}$ Its drama recasts the physician Cerimon as a lord, who revives the woman with air, heat, linens, and music, then exits with the hope, "And Aesculapius guide us!"96 Although this plot lacks the medical examination to which Harvey alludes, its acclamation by London theatregoers guaranteed the timeliness of Apollonius's tale for Harvey's colleagues. Beyond theatrical entertainment, there is a professional reason why the College of Physicians would have attended to Historia Apollonii. Its heroine suffers the female "fit" that their fellow Edward Jorden analysed and dedicated to them as A briefe discourse of a disease called the suffocation of the mother. ${ }^{97}$ It is the original Latin text and its faithful Elizabethan translation of the young disciple's diagnosis and therapy that Harvey recommends. He wants his fellows to repeat to him its master's praise of his pupil, " "My welbeloved schollar Machaon, I am glad of this fortunate chaunce, and I much commende thy wisedome, and praise thy learning, and cannot but extoll thy diligence"," 98

Beyond the casting of characters to play medical roles, Harvey's soliloquy to the College of Physicians signals by its stage direction the plot of his cardiovascular discovery. Harvey tersely records the troubled progress of his anatomies and deliberations, from fluctuating

\footnotetext{
${ }^{92}$ Ibid., pp. 16-18, 22-3, 182-216. For its medieval and renaissance reception, see pp. 45-51.

${ }^{93}$ Laurence Twine, The patterne of painefull adventures, London c. 1576, rpt. 1607, ed. Geoffrey Bullough, in Narrative and dramatic sources of Shakespeare, 8 vols, London, Routledge and Kegan Paul, 1966, vol. 6, p. 449.

${ }^{94}$ George Wilkins, The painfull adventures of Pericles prince of Tyre, London 1608, ed. Kenneth Muir, Liverpool University Press, 1953, pp. 62-5. The erasure of the medical disciple dates to John Gower's Confessio Amantis, in The complete works, ed. G C Macaulay, 4 vols, Oxford, Clarendon, 1899-1902, vol. 4, pp. 417-18.

${ }^{95}$ For the collaboration, see MacDonald $\mathrm{P}$ Jackson, Defining Shakespeare: 'Pericles' as test case, Oxford University Press, 2003; William
}

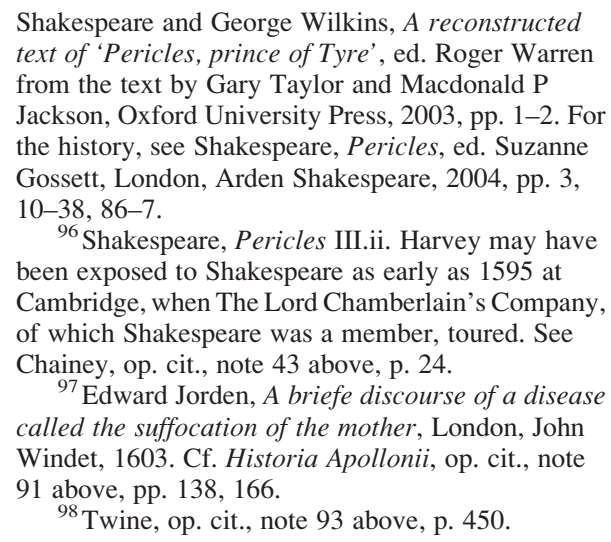
text of 'Pericles, prince of Tyre', ed. Roger Warren from the text by Gary Taylor and Macdonald $\mathrm{P}$ Jackson, Oxford University Press, 2003, pp. 1-2. For the history, see Shakespeare, Pericles, ed. Suzanne Gossett, London, Arden Shakespeare, 2004, pp. 3, 10-38, 86-7.

${ }^{96}$ Shakespeare, Pericles III.ii. Harvey may have been exposed to Shakespeare as early as 1595 at Cambridge, when The Lord Chamberlain's Company, of which Shakespeare was a member, toured. See Chainey, op. cit., note 43 above, p. 24.

${ }^{97}$ Edward Jorden, A briefe discourse of a disease called the suffocation of the mother, London, John Windet, 1603. Cf. Historia Apollonii, op. cit., note 91 above, pp. 138, 166.

${ }^{98}$ Twine, op. cit., note 93 above, p. 450. 


\section{William Harvey's Soliloquy to the College of Physicians}

in the straits of indecision to landing at a grounded site. This destination is also a perilous place, a "labyrinth". By the diligent vivisection and examination of various animals, by the collation of these many observations, and by reasoned arguments, he declares, "I got it, and I escaped clear and free from this labyrinth." 99 This labyrinthine metaphor compresses in a word Harvey's tortuous but triumphant procedures. All metaphors, as Aristotle's rhetoric taught, implied riddles. ${ }^{100}$ But the labyrinth was the archetypal puzzle, by its status appropriate for comparison with Harvey's quasi-divine mystery of the movement of the heart and the blood. John Calvin, whose doctrine then governed the Church of England, taught that God was "an impassible labyrinth" unless believers were guided by the rope of scripture. ${ }^{101}$ Harvey's metaphor is more than appropriate by comparative status, however. For, the labyrinth exposes his very method as he applies his mind to his anatomies.

The labyrinth comprised a pattern and a topic that were often at cultural odds, for labyrinthus denoted both the architectural design of a labyrinth and the literary motif of a maze. It was applied in a dizzying moral of good and evil, spiritual and carnal, from religious processional to amorous tryst. Indeed, Harvey's contemporary world was conceived as a labyrinth, with paradise as its "heart". An architectural labyrinth was a circular design with an identical entrance and egress. One path only wound through it concentrically, folding back and forth circuitously, progressing inevitably to the centre of the circle, which in the ecclesiastical type could be cut with a saving cross. The walking of a labyrinth demanded mental perseverance and physical stamina. A maze was a very different design of multiple apertures and multiple paths. A twisting, tricky plot, it could lead or lose the walker in a blind alley or a dead end as he progressed toward or regressed from the uncertain centre. Cleverness - mental ingenuity and physical agility-was needed for extrication from a maze. No maze was depicted before the Renaissance, when the Venetian physician Giovanni Fontana drew several in his encrypted notebooks. Although he probably conceived them while a medical student at Padua, these first artistic mazes do not depict anatomical parts but military stratagems. In literature a maze, whose many chances for error caused confusion and despair, was commonly miscalled a "labyrinth". A name for these nasty designs was domus Daedali, after the architect who designed the prototypical Cretan labyrinth to enclose the Minotaur, a devouring monster. ${ }^{102}$ When Galileo warned against aimless wandering without geometrical models in a dark "labyrinth", ${ }^{103}$ he typified the scientific maze.

Of the true labyrinthine design, Harvey would not have seen its splendid examples set in stone in medieval church floors, unless perhaps he travelled the route to Padua through Amiens. ${ }^{104}$ In Italy the Veneto had the most labyrinths; but a hedge labyrinth in Padua is mapped only in the late eighteenth century, although one in the local Euganean hills is

${ }^{99}$ Harvey, op. cit., note 1 above, p. 21.

${ }^{100}$ Aristotle, Rhetorica 1405 b.

${ }^{101}$ John Calvin, Institutio christianae religionis 1.6.3, in Opera quae supersunt omnia, ed. Johann Wilhelm Baum, Eduard Cunitz, and Eduard Reuss, 59 vols in 58, Brunswick, C A Schwetshke, 1863-1900, vol. 2 , p. 55

${ }^{102}$ Hermann Kern, Through the labyrinth: designs and meanings over 5,000 years, transl. Abigail Clay, Munich, Prestel, 2000, pp. 23-30, 138-9. See also
Johann Amos Comenius, Das Labyrinth der Welt und das Paradies des Herzens, 1623.

${ }^{103}$ Galileo Galilei, Il saggiatore, in Le opere di Galileo Galilei, ed. A Favaro and I del Lungo, 20 vols, rpt. Florence, Barbèra, 1968, vol. 6, p. 232.

${ }^{104}$ See Thomas Coryat, Coryat's crudites, 2 vols, Glasgow, James MacLehose and Sons for the University, 1905, vol. 1, pp. 162-3, although he does not mention the labyrinth. For the labyrinth at Amiens, see Kern, op. cit., note 102 above, pp. 148-9, 191. 


\section{Marjorie O'Rourke Boyle}

mapped in the late seventeenth century. ${ }^{105}$ England lacked ecclesial labyrinths but it had its characteristic turf labyrinths on church properties, developed from sketches in monastic manuscripts. ${ }^{106}$ Among royal properties Harvey may have known, at Prince Henry's palace of Richmond there was a "daedalus", or labyrinth, centred with a small temple containing a fountain. ${ }^{107}$ This plan seems suggestive of the heart with blood-flow, in Harvey's phrase "the treasury and font". ${ }^{108}$ If he visited Hampton Court, he may have known its maze, which dated to Cardinal Thomas Wolsey's residence. ${ }^{109}$ Further, a leased royal property, the lodgings created from the dissolved Benedictine abbey at Canterbury, where Harvey was schooled, had gardens with both "labirinth like wildernesses" and "wooddy mazes". ${ }^{110}$ Harvey and his colleagues would certainly have learned of the labyrinth as schoolboys reading Vergil's Aeneid. Its "game of Troy", in which youths performed a collective military dance on horseback at the founding of a city, was an initiation rite that traced a labyrinthine design. The ritual renewed the city in the personae of the adolescents, successfully coming of age by extricating themselves from the labyrinth. Vergil also introduced schoolboys to the prototypical Cretan labyrinth of seven circuits winding to a centre. His protagonist, Aeneas, viewed this ekphrastic labyrinth on the Cumean gate at his initiation into the underworld, even as the poet warned, "Here is the labor: that house and inextricable wandering". ${ }^{111}$ It was often the warrior, whether Theseus slaying the Minotaur or Christ the devil, who victoriously penetrated the labyrinth to its centre. ${ }^{12}$ This challenge coheres with Harvey's belligerent declaration, "The die is cast".

Both the labyrinth and the maze are denoted by Harvey's labyrinthus. Initially he is in a maze, the quandary of the multicursal design. Then he figures out that he is actually in a labyrinth, the certainty of the unicursal design. The straits of Euripus may have been anecdotally frustrating for Aristotle, as he states, but their movement was regular like the course of a labyrinth, not erratic like that of a maze. Its tides were observed and recorded since antiquity as timeable. Harvey records that he fluxed and refluxed, back and forth, back and forth, steadily riding on the predictable tides of Euripus. His anatomical probings

\footnotetext{
${ }^{105}$ Roberto Milazzi, 'The labyrinth of Padua', Caerdroia, 1998, 29: 35-7.

${ }^{106}$ Kern, op. cit., note 102 above, pp. 167-70, 10541; Craig Wright, The maze and the warrior: symbols in architecture, theology, and music, Cambridge, MA, Harvard University Press, 2001, p. 20.

${ }^{107}$ See Roy Strong, The Renaissance garden in England, London, Thames and Hudson, 1979, p. 101. The landscape included a hydraulic organ, which may have afforded Harvey an example of his "two clackes of a water bellows to rays water". William Harvey, Anatomical lectures: 'Praelectiones anatomie universalis', 'De musculis', ed. Gweneth Whitteridge, London, E and S Livingstone for the Royal College of Physicians, London, 1964, p. 272.

108 “(quasi è thesauro \& fonte) ... ". Harvey, op. cit., note 1 above, p. 60.

${ }^{109}$ See Kern, op. cit., note 102 above, p. 261. See also Gervase Markham, Certaine excellent and new invented knots and mazes, London, John Marriott, 1623, fig. 10; William Lawson, A new orchard and
}

garden, London, Bar: Alsop for Roger Iackson, 1618, p. 8 , pl. 10 .

${ }^{110}$ Cited by Margaret Sparks, 'The abbey site, 1538-1997', in Richard Gem (ed.), English heritage book of St. Augustine's Abbey, Canterbury, London, B T Batsford and English Heritage, 1997, pp. 143-61, on p. 149.

${ }^{111}$ Vergil, Aeneid 5.546-604. For the game of Troy, see Kern, op. cit., note 102 above, pp. 77-83. For initiation rites, see pp. 30-3, 47; W F Jackson Knight, Cumaean gates: a reference of the sixth 'Aeneid' to the initiation pattern, Oxford, Basil Blackwell, 1936; Penelope Reed Doob, The idea of the labyrinth from classical antiquity through the Middle Ages, Ithaca, NY, Cornell University Press, 1990, pp. 227-53. Vergil, Aeneid 6.570, 6.23-30. "Hic labor ille domus et inextricabilis error", 6.27. Cf. Harvey "extricatum me", op. cit., note 1 above, p. 21.

${ }^{112}$ Wright, op. cit., note 106 above, especially pp. 192-6. 


\section{William Harvey's Soliloquy to the College of Physicians}

in the veins lead him to the confident observation of one certain circuit for the blood-flow; for, the venous wickets did not point willy nilly but all in a single direction. As the design of a labyrinth has been explained, without reference to Harvey, "The path does not move in a straight line but rather in the rhythm of systole and diastole". 113

A labyrinth meant from medieval etymology labor intus, "labour within". ${ }^{114}$ For Harvey, the useful feature of Vergil's labyrinth was its location in the subterranean underworld, analogous to the subcutaneous interior of the human body. The analogy had been established by the essential humanist commentary on Vergil's Aeneid, when Christoforo Landino located its underworld "in the heart of the earth" because it is "in the middle of the earth as the heart is in the middle of the body". ${ }^{115}$ A sixteenth-century book of labyrinths by the Paduan physician and architect Francesco Segala has a woodcut of the human body whose exposed interior is cut with intricate mazes. ${ }^{116}$ How does Harvey in the bodily labyrinth discern the circularity of the blood-flow? Imitating the investigation of his father in anatomy, Fabrici, he enters its labyrinth through an incision in a vein and explores its hollow with his probe. But Harvey perseveres in the path of the venous membranes, probing through those doors swinging forward in an imagined maze that becomes by experience a labyrinth. Harvey penetrates this labyrinth to its centre, the heart, and finds his way out again by a single path circling back to the incised entrance. The circularity of the labyrinth thus coincides with the circulation of the blood. Harvey's diction, ex hoc labyrintho me extricatum euasisse, ${ }^{117}$ indicates that he does not exit the labyrinth on level ground but climbs up and out (euasisse) of it. He thus situates himself as a researcher down below in the body, not only beneath its skin but in its extremities, where Fabrici had terminated the blood-flow.

This bodily labyrinth is like an architectural house, which opens by dissection as if by a door. Harvey's allusion to the pivotal doorway in his citation of Terence's soliloquy accords with the labyrinth as the "house of Daedalus" named after its architect. The house door was a convention of classical literature, especially drama. Literally at centre stage, the door structured the plot, not only by allowing the entrance and exit of characters but also by witnessing the intrigues of lovers unlatching it, murderers bolting it, and gossips eavesdropping through it. "Door" even became a character who was addressed and who spoke. ${ }^{118}$ Knocking on doors that creaked open was a standard stage cue in every comedy of Terence. ${ }^{119}$ Adelphi, the play Harvey addresses to the College, has thirty-five entries and exits by its house door. ${ }^{120}$ Where does its elder Demea, whom Harvey has

\footnotetext{
${ }^{113}$ See Kern, op. cit., note 102 above, p. 24. For the origin of the labyrinth in a rhythmic dance, see pp. 43-7.

${ }^{114}$ Doob, op. cit., note 111 above, pp. 94, 147.

${ }^{115}$ Christoforo Landino, Vergilius cum quinque commentariis (Venice, 1491-92), fol. 230v on Aeneid 6.126. Cited without reference to Harvey by Craig Kallendorf, 'From Virgil to Vida: the poeta theologus in Italian Renaissance commentary', $J$. Hist. Ideas, 1995, 56: 41-62 on p. 51. The location of vv. 125-35 was repeated by Giovanni Fabrini, on p. 56.
}

\footnotetext{
${ }^{116}$ See Kern, op. cit., note 102 above, p. 240, fig. 446.

${ }^{117}$ Harvey, op. cit., note 1 above, p. 21.

${ }^{118}$ See Elizabeth H Haight, The symbolism of the house door in classical poetry, New York, Longmans, Green, 1950.

${ }_{119}$ Duckworth, op. cit., note 49 above, pp. 116-17, 324. See also pp. 415, 423-7.

${ }^{120} \mathrm{~W}$ W Mooney, The house-door on the ancient stage, Baltimore, Williams and Wilkins, 1914, p. 54. For the knocking at Terence, Adelphi line 788, see pp. $27,39,47$.
} 


\section{Marjorie O'Rourke Boyle}

imitated and asks his colleagues to imitate, stand when he soliloquizes about his radical change of mind? In a doorway, the doorway of his contrasting brother's house. ${ }^{121}$

This situation is liminality, like Caesar's station on the border between his assigned province Cisalpine Gaul and his homeland Italy, casting a die to cross the River Rubicon. Anthropology defines liminality as "a realm of pure possibility whence novel configurations of ideas and relations may arise". The concept develops from rites of passage from a stable to an acquired state. The liminal period includes reflection on society and cosmos and their generating and sustaining powers. As Cicero explained, initiations were learnings about the first principles of life, Harvey's preoccupation to understand the heart as the principium of the body. Although liminality centres on cultural and social initiation, such as rites of puberty, it includes entry into "membership of an exclusive club". ${ }^{122}$ Such an exclusive club was the College of Physicians, with its statutory restrictions, examinations, assemblies, ceremonials, dress, precedences, privileges, and prohibitions, fees and finesmuch of it exacted under oath. It was an aristocracy of merit, not of birth; but it both copied that social competition for prestige and depended on belief in its own merit. ${ }^{123}$ And such was Harvey's liminality on the threshold of physiological discovery, where novel configurations of ideas and relations did indeed experimentally arise. Harvey seeks to initiate his colleagues to new knowledge by persuading them to cross the threshold from strict adherence to tradition to lenient behaviour toward him, to change character like the brother in Terence's comedy.

Harvey's metaphors of fluxing in the straits of Euripus then extricating himself from a labyrinth resonate with the classical verse that conflated a labyrinth — actually a mazewith a river. Ovid's Metamorphoses poetized how the archetypal architect, Daedalus, constructed the Cretan labyrinth as a house of numerous blind quarters that enticed an explorer into error through various winding paths. "Just as the watery Meander plays in the Phrygian fields, flows back and forth in doubtful course and, turning back on itself, beholds its own waves going on their way, and sends its uncertain waters now towards their source and now towards the open sea: so Daedalus made those innumerable winding passages, and was himself scarce able to find his way back to the place of entry, so deceptive was the enclosure he had built". ${ }^{124}$ Ovid's word for the labyrinth is domus, "house", whose "entry" is limen, "threshold", the doorway in which Harvey invites his colleagues to stand then cross over with him in the character of Terence's Demea.

As Vergil intoned for Aeneas, the descent into the labyrinthine underworld is easy, "but to recall thy steps and pass out to the upper air, this is the task, this is the toil". ${ }^{125}$ How did Harvey find his way safely through the bodily labyrinth? As an adage advised, "If you go

${ }^{121}$ Ibid., line 854.

${ }^{122}$ See Victor Turner, 'Betwixt and between: the liminality period in rites de passage', in idem, The forest of symbols: aspects of Ndembu ritual, Ithaca, NY, Cornell University Press, 1967, pp. 93-5, 97, 106-7, citing Cicero, De legibus 2.14.

${ }^{123}$ See Clark, op. cit., note 68 above, vol. 1, pp. 90 , 93-4, 101-3, 122-3, 133, 137, 138, 141, 180, 181.

${ }^{124}$ Ovid, Metamorphoses 8.162-66; Metamorphoses, transl. Frank J Miller, 2 vols,
London, William Heinemann, 1960, vol. 1, pp. 417-19. A designed meander differs from a labyrinth because its paths are intersected. Kern, op. cit., note 102 above, p. 23. For Harvey as an explorer of "man's Meander", see Abraham Cowley, 'Ode upon Dr. Harvey', cited in Keynes, op. cit., note 32 above, p. 427.

${ }^{125}$ Vergil, Aeneid 6.128-29; Virgil, transl. H Rushton Fairclough, 2 vols, London, William Heineman, 1967, vol. 1, p. 515. 


\section{William Harvey's Soliloquy to the College of Physicians}

into a labyrinth, take a clew with you". ${ }^{126}$ A clew, modernized clue, is "a ball of thread", derived from the one Theseus heroically unrolled to retrace his path out of the original Cretan labyrinth. Harvey's thread of thought in the bodily labyrinth is his professor Fabrici's observation of the venous wickets (ostiola). Significantly, the only illustrations in Harvey's book are plagiarized engravings from Fabrici's book De venarum ostiolis. ${ }^{127}$ But, in examining these wickets Harvey sympathizes with Francis Bacon's philosophy about unrolling the thread of argument, which criticized the loss of scientific invention to traditional belief and discipleship. As Bacon lamented in Filum labyrinthi ('The Thread of the Labyrinth'), "The succession is between the master and disciple, and not between inventor and continuor or advancer; and therefore the sciences stand at a stay ..." ${ }^{128}$ Harvey picks up his master Fabrici's thread but does not drop the ball in the feet; he holds it fast to the heart. Exploring that deep structure, Harvey imitates the epic hero Aeneas in relation to his father, Anchises. Aeneas tried in the labyrinthine underworld to clasp the shade of his father, whom he had piously carried on his back from Troy-only to have it vanish. After listening to his father's stories, in the end mournful Aeneas leaves Anchises behind to return to the upper world. "With sad countenance and downcast eyes, Aeneas wends his way, quitting the cavern, and ponders the dark issues". ${ }^{129}$ So Harvey in the anatomical depths loses his father, Fabrici, who had opened the vein but failed to follow its path through the membranes to the central heart. ${ }^{130}$

Quintilian's Institutio oratoria taught English schoolboys learning rhetoric to "knock from door to door (ostiatim pulsanda)". Students knocked and knocked to discover whether certain places, or topics, provided material for the invention of argument. ${ }^{131}$ Here Harvey's plot of invention literally thickens. Fabrici had defined, "The wicket[s] of the veins are named by me some exceedingly slender tiny membranes in the internal hollow of the veins ..." . After explaining their occurrence at intervals singly or as twins, Fabrici compared their organic shape to vegetation. They looked to him like "the knots in the fine shoots of plants". The wickets were arranged alternately like the design "in those vegetations, flowers, leaves, and branches that are seen to sprout one after the other from the stem in an opposite spot. For thus the lower wickets always delay what slips past the higher ones; meanwhile, the passage of the blood is not in fact impeded". His book illustrated the analogy by juxtaposing an engraving of a ligated arm with wickets like knots and an engraving of the branches of vervain with similar knots. ${ }^{132}$

\footnotetext{
${ }^{126}$ Tilley, op. cit., note 84 above, p. 365 . See Erasmus, Parabolae sive similia, ed. Jean-Claude Margolin, in Opera omnia, Amsterdam, vol. I-5, p. 272.

${ }^{127}$ Harvey, op. cit., note 1 above, between pp. 56-7. See also Keynes, op. cit., note 32 above, p. 177.

${ }^{128}$ Francis Bacon, Filum labyrinthi, sive formula inquisitionis, in Works, ed. J Spedding, R L Ellis, and D D Heath, 7 vols, London, Longmans, Green and Roberts, 1857-59, vol. 6, p. 419. For Bacon and Harvey, see also Keynes, op. cit., note 32 above, pp. 157-61; French, op. cit., note 2 above, pp. 325-7. ${ }^{129}$ Vergil, Aeneid 6.679-702, 898; 6.156-58;

Fairclough (transl.), op. cit., note 125 above, vol. 1,
}

p. 517. Cf. Harvey's citations of Aeneid 6.726-27 and 10.5.487 in Exercitationes de generatione animalium, London, Octavian Pulleyn, 1651, pp. 83, 248

${ }^{130} \mathrm{Cf}$. Petrucchio in Padua, bidding servants to knock and knock on Hortensius's door to announce the plot: "Antonio, my father, is deceased;/And I have thrust myself into this maze". Shakespeare, Taming of the shrew I.ii.1-55.

${ }^{131}$ Quintilian, Institutio oratoria 5.10 .112 .

${ }^{132}$ Girolamo Fabrici d'Aquapendente, De venarum ostiolis, Padua, 1603, facsimile rpt., ed. and transl. Kenneth J Franklin, London, Baillière, Tindall, and Cox, 1933, pp. 71, 75, 78-81. For ostiolum as "wicket", see John Withals, A short dictionary most 


\section{Marjorie O'Rourke Boyle}

Fabrici could have illustrated his analogy in life by inviting his students outdoors for a lesson in the botanical gardens, which Padua was the first university to create. His engraved herb, verbena officinalis, "vervain", was cultivated there according to the 1591 inventory. ${ }^{133}$ As the English tourist Thomas Coryat reported a decade later, "I went to the goodly garden of the City, that lyeth betwixt the Santo and the Church of St. Justina. It belongeth especially to the Physitians, and is famoused over most places of Christendom for the soveraigne vertue of medicinale hearbes". As for its shape, "It is round like a circle". ${ }^{134}$ Its circular design was divided into four square centred plots, each having various patterns of circles_-some concentric —and also knots. ${ }^{135}$ If Fabrici had walked his students around the perimeter of the garden to observe his botanical analogy for the venous wickets, they would have proceeded in a circle. But he did not so lead them because it was not his job. It was Prospero Alpino, the professor of medical botany, who lectured from Galen's text on simples, and Giacomo Antonio Cortusi, the curator of the botanical garden, who demonstrated the plants. ${ }^{136}$ The botanical garden at Padua was an enclosed garden (hortus conclusus) recreated as an Eden, or earthly paradise. ${ }^{137}$ The type of the enclosed garden was allegorized in biblical exegesis as the womb of the Virgin Mary bearing the Christ child. ${ }^{138}$ The analogy of a circular garden to a bodily interior was culturally viable. The circulatory model as a closed system was observable at Padua's medical school by movement around and around its botanical garden to witness the knots on stems like the wickets in veins. It was not a great intuitive leap from Fabrici's knots in the veins to their source in Plato's definition of the heart as "the knot of the veins". ${ }^{139}$

Or, if Fabrici during his lecture on the venous wickets had looked up from his station, he could have seen an architectural model for the blood's circulation. The permanent anatomical theatre at Padua was constructed of six ascending concentric circles as galleries for observation. There was a single entrance to the theatre, and there were encircling stairs to the tiers with multiple accesses. ${ }^{140}$ The anatomical theatre resembled an indoor

profitable for young beginners, 2nd ed., rev. Lewis Evans, London, Thomas Purfoote, 1581, s.v.; for "little dore, or wicket", John Baret, An aluearaie or quadruple dictionarie containing foure sundrie tongues: namelie, English, Latine, Greeke, and French, 2nd ed., London, Henry Denham, 1580, p. 120. Note that Fabrici's cavitas and the caverna of a labyrinth share the same root.

${ }^{133}$ Elsa M Cappelletti, 'Elenco delle piante coltivate nel 1591', in Alessandro Minelli (ed.), L'orto botanico di Padova: 1545-1995, Venice, Marsilio, 1995, pp. 212, 240. Vervain was native to the British Isles and common in its herbals. E.g. "ueruayne" in William Copland, A boke of the properties of herbes called an herball ... 1568/69. There was no proper medicinal garden at the College of Physicians,

London, however. Clark, op. cit., note 68 above, vol. 1, p. 256.

${ }^{134}$ Coryat, op. cit., note 104 above, vol. 1, pp. 291-2; cf. 290, vol. 2, 384, vol. 1, p. 290.

${ }^{135}$ Margherita Azzi Visentini, L'orto botanico di Padova e il giardino del Rinascimento, Milan,

Polifilo, 1984, pp. 33-104, and figs. on pp. 116, 118;
Andrea Ubrizsy Savoia, 'L'orto di Padova all'epoca del Guilandino', in Minnelli (ed.), op. cit., note 133 above, pp. 173-96, on pp. 188, 191, 193, 194; Vittorio Del Piaz and Maurizio Rippa Bonati, 'L'Horto medicinale dello Studium patavinum: progeto e rappresentazione', in ibid., pp. $33-56$, on pp. $32,36-7$.

${ }^{136}$ See Paul F Grendler, The universities of the Italian Renaissance, Baltimore, Johns Hopkins University Press, 2002, pp. 345-6, 348.

${ }^{137}$ Azzi Visentini, op. cit., note 135 above, p. 38. See also John Prest, The garden of Eden: the botanic garden and the re-creation of paradise, New Haven, CT, Yale University Press, 1981.

${ }^{138}$ Song 4:12. E Ann Matter, The voice of $m y$ beloved: the Song of Songs in western medieval Christianity, Philadelphia, University of Pennsylvania Press, 1990, pp. 154, 162-3.

${ }^{139}$ Plato, Timaeus 70b; The dialogues of Plato, transl. Benjamin Jowett, 4 vols, 4th ed. rev., Oxford, Clarendon, 1964, vol. 3, p. 757.

${ }^{140}$ Kenneth J Franklin (ed.), Fabrici d'Aquapendente, op. cit., note 132 above, pp. 25-9; 
amphitheatre, and the great Renaissance architect Leon Battista Alberti had used Fabrici's ostiola as hostiolum for the gates to the Roman circus. ${ }^{141}$ Yet, Fabrici did not associate the circulatory model before his very eyes-his students encircled around him-with his demonstration of the venous wickets. To open those venous wickets, Harvey rehearses the classical comedic formula of knocking on doors, not for farcical effect but for serious result. Although he is not on a theatrical stage but in an anatomical theatre, in his experience at Padua they were virtually equivalent venues. The construction of the permanent anatomy theatre there promoted - celebrated-Fabrici's demonstrations. The free admission of the public, the formal processionals and orations, and the musical entertainments rendered his academic exercise a dramatic performance. The cadavers were no longer dissected on site but prepared in an inner room-off stage as it were, for Fabrici's privileged exhibition of them to his audience. ${ }^{142}$

Harvey's knocking on his master's "little dores" observes the Hippocratic Oath. "Into whatever houses I enter", physicians swore, "I shall enter to help the sick". ${ }^{143}$ How to enter houses? By doors. Once inside the doorway, Harvey discovers the heart as lares, Lar familiaris, lares focumque, the household god at the hearth. ${ }^{144}$ His reference is both literary and philosophical. In the prologue of Plautus's comedy Aulularia ('The Pot of Gold') the character Lars familiaria announces its plot about a secret treasure, a horde of gold buried by a miser "in the midst of the hearth". ${ }^{145}$ Harvey develops in De generatione animalium his architectural conceit of the heart dwelling in the breast like a household god (lars familiaris) concealed in an intimate secret room, and governing the entire domicile with servile lungs. ${ }^{146}$ Harvey's Lar/lares also relates to Aristotle's cardiocentrism, which literally focused the heart as the hearth. Harvey reasoned from Aristotle's natural philosophy that the heart contained and conserved on its burning hearth the natural kindling that maintained the body's vital heat. ${ }^{147}$ If that heat was not to be extinguished, the fire would need restoking. Thus the blood supply would need to return to its hot source. That source was centralized: traditional domestic hearths were not positioned against a wall but set in the middle of the principal room. ${ }^{148}$ To find the inner secret of the bodily house, the

Cynthia Klestinec, 'A history of anatomy theaters in sixteenth-century Padua', J. Hist. Med. Allied Sci., 2004, 59: 375-412, on pp. 399-400. For concentric circles and labyrinths, see Kern, op. cit., note 102 above, p. 23.

${ }^{141}$ Leon Battista Alberti, L'Architettura [De re aedificatoria], ed. Giovanni Orlandi, 2 vols, Milan, Polifilo, 1966, vol 2, p. 751.

${ }^{142}$ See Klestinec, op. cit., note 140 above, pp. 381, 399-409.

${ }^{143}$ Hippocratic 'Oath', op. cit., note 63 above, pp. 300-1.

${ }^{144}$ Harvey, op. cit., note 1 above, pp. 42, 59.

Roman lares may have been ancestors worshipped at the hearth, for they were described as sooty. David G Orr, 'Roman domestic religion: the evidence of the household shrines', in Aufstieg und Niedergang der römischen Welt: Geschichte und Kultur Roms im Spiegel der neueren Forschung, ed. Hildegard Temporini, Berlin, De Gruyter, 1972, 2.16. vol. 2, pp. 1564, 1566, 1567.

\footnotetext{
${ }^{145}$ Plautus, Aulularia prol.

${ }^{146}$ William Harvey, op. cit., note 129 above,
} pp. $54,183,250$.

${ }^{147}$ Harvey, op. cit., note 1 above, pp. 58-9. See Gad Freudenthal, Aristotle's theory of material substance: heart and pneuma, form and soul, Oxford, Clarendon, 1995, pp. 19-35, 130-4, 182; Philip J van der Eijk, 'Aristotle's psycho-physiological account of the soul-body relationship', in John P Wright and Paul Potter (eds), Psyche and soma: physicians and metaphysicians on the mind-body problem from antiquity to enlightenment, Oxford, Clarendon, 2000, pp. 57-77, on pp. 68-9. Aristotle, De partibus animalium 670a; cf. Thomas Aquinas, Super ad Hebraeos 2.3 .

${ }^{148}$ See Angela Della Volpe, 'From the hearth to the creation of boundaries', J. of Indo-European Stud., 1990, 18: 157-84, on pp. 158-60; Paul Veyne, 'The Roman house', in Paul Veyne and Georges Duby (eds), A history of private life, vol. 1: From pagan Rome to Byzantium, transl. Arthur Goldhammer, 5 


\section{Marjorie O'Rourke Boyle}

treasure at the hearth, Harvey follows the classical rhetorical method of knocking from door to door (ostiatim pulsanda) for the invention of argument. Knocking continually on Fabrici's "little dores" with his probe, Harvey bangs them down flat and discovers the source of pulsation itself, the heart at the centre of the labyrinth. By probing the veins Harvey learns what his father in medicine had not: that his wickets flatten to allow the blood-flow but retract to prevent its backup. Moreover, the venous wickets all flatten in the same direction. Harvey reasons that, since they incline one way, they can be followed on a route, the unicursal design of the labyrinth. ${ }^{149}$

Practitioners of medicine have adopted Harvey's progressive role and trooped over the threshold of his discovery. Historians of medicine, however, must cross backward over that threshold to his situation in front of the doorway. In playing that regressive part an understanding of his culture matters. His classical literary citations and allusions are not flowery ornaments that decorate, worse detract from, the scientific record. They speak his mind eloquently but subversively as arguments for an unclassical medicine.

vols, Cambridge, MA, Harvard University Press, Belknap Press, 1987-91, pp. 315-17, on p. 315; Michael Rouche, 'The early Middle Ages in the West', in ibid., pp. 411-549, on p. 495; Robert Fossier,

Peasant life in the medieval West, transl. Juliet Vale, Oxford, Basil Blackwell, 1988, pp. 68-9; Norman J G Pounds, Hearth and home: a history of medieval culture, Bloomington, Indiana University Press, 1989, pp. 194-5; Jean Chapelot and Robert Fossier, The village and house in the Middle Ages, transl. Henry Cleere, London, B T Batsford, 1985, pp. 193, 217-19.
${ }^{149}$ For the later report from memory of a conversation that the venous membranes originated Harvey's invention of the blood's circulation, see Robert Boyle, Disquisition about the final causes of natural things, in The works of Robert Boyle, ed. Michael Hunter and Edward B Davis, 14 vols, London, Pickering and Chatto, 1999-2000, vol. 12, p. 129. Among historians who consider Harvey's research on the venous membranes "central", see especially French, op. cit., note 2 above, pp. 350-59; Boyle, op. cit., note 13 above. 